shocks were felt within twenty-four hours at widely separated points, running from Bandargaz to Kalat. The towns of Shirvan, Bujnurd and Jajarm were severely damaged, and a thousand people were killed in Askhabad. A cleft three yards wide is reported to have been opened between the towns of Khaki and Bagham, to a distance of eighteen miles. The total Persian casualties were 3,253 killed, 1,121 injured, 88 villages destroyed and 6,542 cattle injured. Further news is awaited concerning the present earthquake.

\section{International Council of Scientific Unions}

THe annual meeting of the Executive Committeo of the International Council of Scientific Unions was held at Brussels in September, Prof. E. Borel presiding in the absence of the president, Dr. J. A. Fleming. A resolution from the Royal Society was adopted, that all adhering bodies, national academies and scientific unions be consulted before the Executive Committee accepts any new union. A resolution from the United States asking the Council to consider its constitution and the distribution of subjects covered by the Unions was referred to a committee in the hopes that a report might be available for discussion at the next General Assembly of the Council at Copenhagen during September 14-15, 1949. New joint commissions between the unions were agreed upon to deal with standards and units of radioactivity, spectroscopy, and high-altitude research stations. The adhesion of one new country, Pakistan, was reported. The recommendation from the Committee of Science and Social Relations that a journal should be started by the Committee was referred to the General Assembly. Dr. Establier was reappointed liaison officer with Unesco; representatives of Unesco present at the meeting were Prof. P. Auger and Dr. Wang-hsi-chin.

\section{International Commission on Glass}

THE International Commission on Glass held its first post-war meetings at Sheffield and Buxton during September 30-October 2 under the presidency of Prof. W. E. S. Turner. Decisions were taken to revise the constitution of the Commission, and arrangements were made for the preparation of scientific and technical reports on subjects of fundamental importance in glass technology. Until the adoption of the new constitution, the following comprise the International Commission: Prof. A. H. M. Andreasen (Denmark); Prof. J. A. de Artigas (Spain); Dr. B. P. Dudding (Great Britain, honorary secretary); Dr. M. Fanderlik (Czechoslovakia); Prof. P. Gilard (Belgium); Dr. J. C. Hostetter (United States); Dr. B. Long (France); Dr. H. Maurach (Germany); Dr. Atma Ram (India); B. Simmingsköld (Sweden); Dr. J. A. Stevels (Holland); Prof. W. E. S. Turner (Great Britain, president).

\section{American Physical Society: Division of Fluid Dynamics}

THE Division of Fluid Dynamics of the American Physical Society, which was established by the Council of the American Physical Society in June 1947, has been organised, and the following have been elected members of the Executive Committee : Jesse W. Beams, Howard W. Emmons (secretary-treasurer), Theodor von Kármán, Hugh L. Dryden (vice-chair. man), Paul S. Epstein, Raymond J. Seeger (chair. man), and John G. Kirkwood. The first meeting of the new Division took the form of a one-day sym. posium on June 23, when the Division joined with the University of California at Los Angeles, the University of Southern California, and the California Institute of Technology as part of a three-day meeting to discuss heat transfer and fluid dynamics.

\section{British Museum (Natural History)}

THE southern half of the Invertebrate Gallery (which used to be known as the Starfish Gallery) in the Zoological Department of the British Museum (Natural History) has now been re-opened. The Gallery was dismantled during the War, and an entirely new arrangement of starfishes and other Echinoderms has been prepared, showing many species in their vivid natural colours. Their useful. ness to man and their methods of feeding and breeding are among the subjects illustrated in the new exhibit. In addition to Echinoderms the Gallery is being used temporarily to house a full-sized model of a giant squid, and a small selection of shells. These have been chosen mainly for some interesting peculiarity ; there is, for example, a display of venomous cone shells. A series of common British shells is also exhibited. Certain groups of small invertebrates are also on view here, notably the great group of worms, including earthworms, leeches, many marine forms and parasites. Another new feature is a large-scale relief map coloured to indicate the main movements of the oceans, and the zoo-geographic regions into which the land masses are usually grouped for purposes of biological study.

\section{National Certificates in Textiles}

THE Textile Institute, which is jointly responsible with the Ministry of Education for the award of national certificates in textiles, announces that this year there were 131 entrants for the ordinary certificate, of whom 109 passed, and 85 for the higher certificate, of whom 82 were successful. Fifteen distinctions were obtained in the Higher National Certificate examination. Of the 191 successful candidates, 125 studied cotton subjects, 46 woollen and worsted, and 20 studied general textile subjects.

\section{University of Sheffield: Appointments}

THE following appointments have been made in the University of Sheffield : Dr. William Hobson, senior lecturer in preventive medicine in the University of Bristol, to the newly instituted chair of social and industrial medicine; Miss Ellinor I. Black, senior lecturer in the Department of Social Science, University of Liverpool, to be director of the newly instituted Department of Social Studies; S. Arm. strong, lecturer in civil engineering; Dr. A. E. Beet, at present demonstrator in fuel technology, to be lecturer in fuel technology; A. W. Nicholls, assistant lecturer in glass technology; P. H. Price, research assistant to the professor of fuel technology; James S. Hough, research demonstrator in botany ; P. Wright, Glass Delegacy research fellow.

\section{Announcements}

SIR WALTER MoberLY, chairman of the University Grants Committee, will deliver the Rede Lecture in the University of Cambridge on November 18. He will speak on "Universities and the State".

For the future, the Universities Bureau of the British Empire will be known as "The Association of Universities of the British Commonwealth". Its new address is 32 Woburn Square, London, W.C.1 (Telephone No. : Museum 4578/9). 